\title{
STRATEGI PEMASARAN PADA PT NUANSA WISATA PRIMA NUSANTARA TOUR \& TRAVEL JEMBER
}

\author{
Hilmi Ichwa Salam ${ }^{1}$, Joko Widodo ${ }^{2}$, Mukhamad Zulianto ${ }^{3}$ \\ ${ }^{1}$ Program Studi Pendidikan Ekonomi, Fakultas Keguruan dan Ilmu Pendidikan, Universitas Jember \\ e-mail: 140210301060@ students.unej.ac.id
}

\begin{abstract}
Abstrak
Strategi pemasaran merupakan bagian yang sangat penting dalam pelaksanaan strategi perusahaan secara keseluruhan, terutama dalam keadaan pesaing yang sangat ketat. Persaingan bisnis saat ini yang cukup ketat yaitu bisnis yang bergerak dibidang jasa pariwisata. PT. Nuansa Wisata Prima Nusantara Tour \& Travel Jember adalah salah satu perusahaan yang bergerak dalam industri pariwisata khususnya dalam bidang biro perjalanan yang terdapat di kota Jember. PT. Nuansa Wisata Prima Nusantara Tour \& Travel Jember dalam melaksanakan kegiatan usahanya tidak terlepas dari kondisi persaingan pasar yang semakin kompetitif yang ditandai dengan maraknya usaha yang sejenis di kabupaten Jember. Oleh sebab itu menerapkan strategi pemasaran yang baik dan tepat merupakan salah satu cara yang sangat menentukan bisnis dibidang jasa pariwisata agar kegiatan usaha dapat terus berjalan. Penelitian ini menggunakan jenis penelitian deskriptif dengan pendekatan kualitatif yang bertujuan untuk mengetahui, mendiskripsikan dan menjelaskan keadaan yang sebenar-benarnya terkait tentang strategi pemasaran yang dilakukan oleh perusahaan jasa PT. Nuansa Wisata Prima Nusantara Tour \& Travel Jember. Metode pengumpulan data menggunakan metode wawancara, metode observasi dan metode dokumen. Analisis data yang digunakan pada penelitian ini terdiri dari beberapa tahap yaitu tahap reduksi data, tahap penyajian data dan tahap penarikan kesimpulan. Hasil penelitian menunjukan bahwa perusahaan jasa PT. Nuansa Wisata Prima Nusantara Tour \& Travel Jember menggunakan strategi pemasaran terkait bauran pemasaran yang diantaranya produk (product), harga (price), tempat (place), promosi (promotion), orang/SDM (people), bukti fisik (physical evidence) dan proses (process) dalam menjalankan usaha jasanya.
\end{abstract}

Kata kunci: Strategi Pemasaran, Tour \& Travel.

\section{PENDAHULUAN}

Era globalisasi merupakan masa dimana perusahaan akan bergerak pada satu pasar di dunia yang mengakibatkan persaingan bisnis semakin ketat dan tajam, baik di pasar domestik (nasional) maupun di pasar internasional. Disamping itu kemajuan teknologi komunikasi juga berperan dalam peningkatan intensitas persaingan bisnis. Persaingan bisnis saat ini yang cukup ketat yaitu bisnis yang bergerak dibidang jasa pariwisata. Semakin tinggi persaingan tersebut memberikan isyarat bahwa setiap perusahaan harus memperkuat diri dengan cara memperbaiki dan menciptakan konsep baru dalam mengelola usahanya agar perusahaan tersebut bisa tetap bertahan dan berkembang. Oleh sebab itu menerapkan strategi pemasaran yang baik dan tepat merupakan salah satu cara yang sangat menentukan bisnis dibidang jasa pariwisata agar kegiatan usaha dapat terus berjalan.

Strategi pemasaran merupakan bagian yang sangat penting dalam pelaksanaan strategi perusahaan secara keseluruhan, karena didalam strategi pemasaran terdapat rencana-rencana dan tindakan untuk mencapai sasaran perusahaan di pasar dan dapat mengembangkan keunggulan bersaing yang berkesinambungan. Menurut Tull dan Kahle (dalam Tjiptono, 2002:6) Strategi pemasaran diartikan sebagai alat fundamental yang direncanakan untuk mencapai tujuan perusahaan dengan mengembangkan keunggulan bersaing yang berkesinambungan melalui pasar yang dimasuki dan program pemasaran yang digunakan untuk melayani pasar sasaran tersebut. Apabila hal ini dapat dilakukan oleh perusahaan dengan baik dan tepat, maka konsumen yang telah menggunakan produk jasa tersebut akan lebih terikat dengan perusahaan, sehingga keuntungan jangka panjang perusahaan bisa terjamin.

Perusahaan yang bergerak dibidang jasa perjalanan wisata, strategi pemasaran menjadi solusi sebagai alat untuk dapat menarik calon konsumen agar calon konsumen tersebut berminat menggunakan produk yang ditawarkan, akan tetapi dalam menawarkan jasa bukanlah hal yang cukup mudah, karena bisnis yang bergerak dibidang jasa seperti jasa pariwisata dibidang biro perjalanan, konsumen dapat merasakan jasa tersebut setelah memakai produk jasa yang telah ditawarkan. Kotler (dalam Lupiyoadi, 2013:7) jasa merupakan setiap tindakan atau kegiatan yang dapat ditawarkan oleh satu pihak kepada pihak lain, pada dasarnya tidak berwujud dan tidak mengakibatkan perpindahan kepemilikan apapun. Oleh karena itu, strategi yang ditetapkan pada bisnis jasa 
berbeda dengan strategi yang ditetapkan dalam pemasaran barang.

Strategi pemasaran yang biasa digunakan untuk perusahaan yang bergerak dibidang jasa biasanya menggunakan strategi bauran pemasaran (marketing mix). Kotler (dalam Alma \& Hurriyati, 2008:154) menyatakan bauran pemasaran adalah sekumpulan alat yang dapat digunakan oleh perusahaan untuk mencapai tujuan pemasarannya dalam pasar sasaran. Menurut Kotler dan Keller (2008:4) untuk pemasaran jasa diperlukan bauran pemasaran yang diperluas dengan penambahan unsur yang telah berkembang. Alat pemasaran tersebut dikenal dengan istilah "4P" dan dikembangkan menjadi "7P" yang dipakai sangat tepat untuk pemasaran jasa. Penambahan unsur bauran pemasaran jasa dilakukan antara lain karena jasa memiliki karakteristik yang berbeda dengan produk, yaitu tidak berwujud, tidak dapat dipisahkan, beraneka ragam dan mudah lenyap. Seperti yang dikemukakan oleh Zeithaml dan Bitner (dalam Alma dan Hurriyati, 2008:155) bauran pemasaran jasa terdiri dari 7P yaitu product, price, promotion,place, people, physical evidence dan process.

PT. Nuansa Wisata Prima Nusantara Tour \& Travel Jember adalah salah satu perusahaan yang bergerak dalam industri pariwisata khususnya dalam bidang biro perjalanan yang terdapat di kota Jember. Biro perjalanan ini muncul seiring dengan semakin berkembangnya kegiatan pariwisata dan perjalanan bisnis di Kabupaten Jember. Yoeti (dalam Alma, 2014:350) mengemukakan bahwa biro perjalanan merupakan suatu perusahaan yang menyelenggarakan, merencanakan dan mengurus segala sesuatu mengenai perjalanan, pengadaan penginapan dan hiburan bagi para wisatawan atau orang-orang yang mengadakan perjalanan. PT. Nuansa Wisata Prima Nusantara Tour \& Travel Jember dalam melaksanakan kegiatan usahanya tidak terlepas dari kondisi persaingan pasar yang semakin kompetitif yang ditandai dengan maraknya usaha yang sejenis di kabupaten Jember.

Sasaran paket wisata PT. Nuansa Wisata Prima Nusantara Tour \& Travel Jember adalah intansi, keluarga dan pelajar/mahasiswa. Mayoritas pengguna paket wisata adalah mahasiswa atau pelajar sekolah yang hendak melakukan study tour dan rekreasi bersama yang diadakan rutin tiap tahunnya. Penyebab utama persaingan ketat biro jasa perjalanan adalah persamaan produk paket wisata yang ditawarkan. Oleh karena itu biro perjalanan bersaing pada harga dan produk yang menarik dan produk pelengkap berupa saranan prasarana seperti bis dan rute wisata, serta pelayanan yang memuaskan. Hal-hal inilah yang cukup mempengaruhi hasil penjualan paket wisata dari jasa biro perjalanan.

Ketika menghadapi persaingan dengan perusahaan yang sejenis tentunya pihak manajemen PT. Nuansa Wisata Prima Nusantara Tour \& Travel Jember harus waspada terhadap segala situasi dan kondisi yang akan terjadi dan memerlukan berbagai alternatif strategi pemasaran yang tepat. Semakin ketatnya persaingan serta permintaan konsumen yang berubah-ubah mendorong perusahaan untuk selalu mencari solusi atau alternatif strategi yang paling baik untuk digunakan sebagai langkah kebijakan dalam mencapai tujuan perusahaan.Berdasarkan pemaparan di atas, maka peneliti bermaksud mengadakan penelitian yang bertujuan untuk mengetahui, mendeskripsikan serta menjelaskan strategi pemasaran pada PT. Nuansa Wisata Prima Nusantara Tour \& Travel Jember.

\section{METODE}

Penelitian ini menggunakan jenis penelitian deskriptif dengan pendekatan kualitatif yang bertujuan untuk mengetahui, mendiskripsikan dan menjelaskan keadaan yang sebenar-benarnya terkait tentang strategi pemasaran yang dilakukan oleh perusahaan jasa PT. Nuansa Wisata Prima Nusantara Tour \& Travel Jember. Penentuan lokasi penelitian menggunakan metode purposive area. Metode pengumpulan data yang digunakan peneliti meliputi metode wawancara, metode observasi dan metode dokumen. Analisis data yang digunakan pada penelitian ini terdiri dari beberapa tahap yaitu tahap reduksi data, tahap penyajian data dan tahap penarikan kesimpulan.

\section{HASIL DAN PEMBAHASAN}

\section{Hasil Penelitian}

PT Nuansa Wisata Prima Nusantara Tour \& Travel Jember dalam menentukan strategi pemasaran tidak terlepas dari kebijakan yang telah dibuat oleh perusahaan itu sendiri. Strategi pemasaran yang dilakukan PT Nuansa Wisata Prima Nusantara Tour \& Travel Jember mengacu pada bauran pemasaran jasa diantaranya strategi produk. Produk yang dihasilkan PT. Nuansa Wisata Prima Nusantara Tour \& Travel Jember berupa layanan jasa yang berhubungan dengan perjalanan wisata untuk memenuhi kebutuhan konsumen baik berupa alat transportasi, pemesanan tiket pesawat, pengurusan dokumen perjalanan, pengorganisasian perjalanan Haji dan Umroh, paket Golf. dan segala bentuk pelayanan yang diberikan perusahaan pada konsumen

PT Nuansa Wisata Prima Nusantara Tour \& Travel Jember dalam menarik konsumen tidak lepas dari adanya strategi produk yang sudah dilakukan. Strategi produk yang dilakukan diantaranya adanya customize 
pada produk wisata dan memberikan paket wisata yang fleksibel, dimana perusahaan memberikan pilihan destinasi beragam yang dapat diubah atau disesuaikan dengan kebutuhan konsumen. Adanya paket tour berupa paket keluarga juga menjadi salah satu strategi produk yang dimiliki PT. Nuansa Wisata Prima Nusantara Tour \& Travel Jember, dimana paket keluarga ini jarang sekali dimiliki oleh pesaing. Sehingga paket keluarga akan menjadi nilai lebih bagi perusahaan.

Penentuan harga di PT. Nuansa Wisata Prima Nusantara Tour \& Travel Jember menggunakan strategi penetapan harga dengan tetap mempertimbangkan biaya-biaya yang dikeluarkan perusahaan, dan juga menggunakan strategi harga pasar yang disesuaikan, dimana menetapkan harga jual dengan melihat harga-harga yang telah ditetapkan oleh pesaing di pasar. Selain mempertimbangkan biaya-biaya dan kondisi pasar serta harga pesaing PT. Nuansa Wisata Prima Nusantara Tour \& Travel Jember dalam menetapkan strategi harga juga sesuai dengan daya beli atau permintaan konsumen. Dengan adanya penetepan harga yang disesuai permintaan maka konsumen memiliki kemampuan untuk membeli barang yang ditawarkan oleh perusahaan, sehingga konsumen bisa merasakan indahnya berwisata sesuai dengan kebutuhan dan keinginannya. Ditambah lagi perusahaan jasa tersebut memberikan potongan harga bagi konsumen. Hal ini dilakukan karena adanya persaingan yang ketat sehingga perlu strategi jitu untuk memenangkannya.

Sebagai perusahaan yang sudah cukup lama berdiri PT Nuansa Wisata Prima Nusantara Tour \& Travel Jember mengalami perkembangan yang cukup signifikan didalam perjalanannya, sehingga manager memandang perlu untuk mengembangkan usahanya yang lebih baik lagi. Salah satu langkah yang diambil dengan menerapkan strategi tempat yaitu berpindah lokasi yang lebih besar, strategis dan pastinya mudah dijangkau. Lokasi kantor yang dipilih berada di Jl. Karimata No. 58 Jember. Hal ini dikarenakan tempat tersebut sangat stategis dekat dengan pusat kota dan lebih mendekati sasaran konsumen yaitu intansi, pelajar dan mahasiswa. Sedangkan kegiatan promosi yang dilakukan PT Nuansa Wisata Prima Nusantara Tour \& Travel Jember diantaranya promosi melalui Pengiklanan (Advertising), promosi yang dilakukan PT Nuansa Wisata Prima Nusantara Tour \& Travel Jember dengan pengiklanan yaitu dengan cara melalui media cetak dan media elektronik seperti surat kabar, brosur, kartu nama televisi dan radio.

PT Nuansa Wisata Prima Nusantara Tour \& Travel Jember juga melakukan promosinya melalui penjualan perseorangan (Personal selling). Cara yang digunakan oleh PT Nuansa Wisata Prima Nusantara Tour \& Travel Jember dalam penjualan perorangan adalah dengan memberikan surat penawaran kepada calon peserta tour yang disertai fasilitas-fasilitas yang diberikan oleh perusahaan. Selain promosi menggunakan penjualan perorangan (Personal selling), PT Nuansa Wisata Prima Nusantara Tour \& Travel Jember juga melakukan promosinya melalui Pemasaran Langsung (Direct Marketing). Promosi tersebut dilakukan melalui media sosial seperti: Email, Instagram, Facebook Twitter dan Web.

Perusahaan jasa dapat membedakan dirinya dengan cara merekrut dan melatih karyawan yang lebih mampu dan lebih dapat diandalkan dalam berhubungan dengan pelanggan daripada karyawan pesaingnya. Oleh karena itu PT Nuansa Wisata Prima Nusantara Tour \& Travel Jember dalam melakukan perekrutan karyawaan lebih mencari dan memilih orang yang sudah profesional dalam bekerja, bertanggung jawab, good looking dan berpengalaman. PT Nuansa Wisata Prima Nusantara Tour \& Travel Jember juga memberikan pelatihan mengadakan evaluasi kinerja pada karyawan. Pelatihan tersebut bertujuan agar para karyawan memiliki pengetahuan, kemampuan dan keterampilan sesuai dengan tuntutan pekerjaan yang dilakukan.

Penampilan fisik suatu perusahaan sangat berpengaruh terhadap konsumen untuk menggunakan produk jasa yang ditawarkan, Unsur-unsur lingkungan fisik yang terdapat pada PT Nuansa Wisata Prima Nusantara Tour \& Travel Jember diantaranya berupa fasilitas kantor yang lengkap untuk memudahkan staff dalam melaksanakan tugasnya sekaligus memberikan kepuasan pelayanan kepada konsumen. Peralatan kantor seperti seragam (uniform) kerja yang menarik juga diadakan oleh perusahaan. Unsur fisik bangunan PT Nuansa Wisata Prima Nusantara Tour \& Travel Jember yang memiliki desain nyaman serta arsitektur bangunan yang representatif juga diharapkan dapat mempengaruhi ketertarikan calon konsumen. Tidak hanya itu PT Nuansa Wisata Prima Nusantara Tour \& Travel Jember juga memiliki cafetaria yang sangat cocok untuk proses transaksi. Dengan adanya cafetaria tersebut diharapkan dapat memberikan nilai tambah bagi perusahaan sehingga konsumen lebih tertarik untuk menggunakan jasa yang ditawarkan.

Strategi proses yang dilakukan PT Nuansa Wisata Prima Nusantara Tour \& Travel Jember adalah mencakup pemberian doorprize dan dokumentasi kepada para peserta tour, dengan tujuan menyenangkan hati peserta tour. Atribut dan pernak-pernik juga perusahaan jasa tersebut persiapkan seperti spanduk acara, banner dan lain-lain. Selama berwisata PT. Nuansa Wisata Prima Nusantara Tour \& Travel Jember menjamin adanya asuransi, karena memastikan konsumen selamat hingga akhir acara, dan asuransi dapat diklaim apabila terjadi kecelakaan atau memenuhi syarat diajukan klaim tersebut. 


\section{Pembahasan}

Sesuai dengan strategi pemasaran yang dilakukan oleh PT. Nuansa Wisata Prima Nusantara Tour \& Travel Jember yang mengacu pada strategi bauran pemasaran dapat dijelasakan bahwa produk merupakan salah satu elemen penting dalam bauran pemasaran, karena produk akan menjadi variabel yang menentukan dalam kegiatan usaha, Menurut Kotler (dalam Alma \& Hurriyati, 2008:156) produk jasa merupakan suatu yang dapat ditawarkan produsen untuk diperhatikan, diminta, dicari, dibeli, digunakan atau dikonsumsi pasar sebagai pemenuhan kebutuhan atau keinginan pasar yang bersangkutan. Begitu juga dengan PT. Nuansa Wisata Prima Nusantara Tour \& Travel Jember memiliki produk jasa yang ditawarkan berupa layanan jasa yang berhubungan dengan perjalanan wisata untuk memenuhi kebutuhan dan keinginan konsumen

Menurut Tull dan Kahle (dalam Tjiptono, 2002:6) strategi pemasaran adalah alat fundamental yang direncanakan untuk mencapai tujuan perusahaan dengan mengembangkan keunggulan bersaing yang berkesinambungan melalui pasar yang dimasuki dan program pemasaran yang digunakan untuk melayani pasar sasaran tersebut. Hal ini menjelaskan bahwa PT Nuansa Wisata Prima Nusantara Tour \& Travel Jember dituntut untuk menerapkan strategi yang tepat bagi kegiatan pemasarannya termasuk strategi produk agar dapat bersaing dengan pesaingnya. Strategi produk yang dilakukan diantaranya adanya customize pada produk wisata dan paket wisata yang fleksibel. Sedangkan strategi produk yang digunakan oleh PT Nuansa Wisata Prima Nusantara Tour \& Travel Jember untuk menarik konsumen adalah membuat produk yang sesuai dengan permintaan pasar. Strategi produk tersebut berupa paket tour yaitu paket keluarga, dimana paket ini merupakan sebuah paket wisata yang ditujukan kepada setiap keluarga yang menginginkan untuk berwisata

Strategi bauran pemasaran ditinjau dari segi harga juga berperan penting dalam bauran pemasaran, karena perusahaan akan sukses dalam memasarkan barang atau jasa apabila dapat menetapkan harga secara tepat. Kotler dan Amstrong (dalam Tjiptono, 2002:154) mengemukakan bahwa perusahaan dalam menetapkan harga harus memperhatikan faktor internal dan faktor eksternal perusahaan. Faktor internal salah satunya yaitu biaya. Biaya ini merupakan faktor yang menentukan harga mininal yang harus ditetapkan agar perusahaan tidak mengalami kerugian. Sedangkan untuk faktor eksternal berupa Sifat pasar dan permintaan, dimana setiap perusahaan perlu memahami sifat pasar dan permintaan yang dihadapi. Hal ini sesuai penetapan harga pada PT. Nuansa Wisata Prima Nusantara Tour \& Travel Jember menggunakan strategi penetapan harga dengan mempertimbangkan biaya-biaya yang dikeluarkan perusahaan.

Sesuai dengan dua faktor penetapan harga tersebut bahwa selain tetap mempertimbangkan biaya, PT. Nuansa Wisata Prima Nusantara Tour \& Travel Jember dalam penetapan harga juga memperhatikan dari faktor eksternal dengan melihat kondisi dan sifat pasar. Strategi ini dengan menetapkan harga jual melihat harga-harga yang telah ditetapkan oleh pesaing di pasar. Oleh karena itu PT. Nuansa Wisata Prima Nusantara Tour \& Travel merasa perlu memperhatikan harga pesaing. Selain itu perusahaan jasa tersebut menetapkan strategi harga juga sesuai dengan daya beli atau permintaan konsumen. Dengan adanya penetapan harga yang disesuai permintaan maka konsumen memiliki kemampuan untuk membeli barang yang ditawarkan oleh perusahaan.

Strategi tempat bisa diartikan sebagai pemilihan tempat usaha dan pemilihan tempat untuk pelayanan kegiatan wisata. Keputusan mengenai lokasi pelayanan yang digunakan akan memudahkan PT Nuansa Wisata Prima Nusantara Tour \& Travel Jember dalam proses penyampaian jasa kepada para konsumen. Menurut Lupiyoadi (2013:96) menyatakan, lokasi (berhubungan dengan sistem penyampaian) dalam jasa yang merupakan gabungan antara lokasi dan keputusan atas saluran distribusi. Hal tersebut berhubungan dengan cara penyampaian jasa kepada konsumen dengan menempatkan letak lokasi yang strategis. Berdasarkan pengertian diatas bahwa strategi tempat yang strategis tersebut sesuai dengan yang dilakukan oleh PT Nuansa Wisata Prima Nusantara Tour \& Travel Jember dimana perusahaan tersebut mengambil suatu langkah yaitu berpindah lokasi yang lebih besar, strategis dan pastinya mudah dijangkau. Tempat stategis tersebut dekat dengan pusat kota dan lebih mendekati sasaran konsumen yaitu intansi, pelajar dan mahasiswa.

Promosi merupakan bagian dari variabel dalam bauran pemasaran yang sangat penting. Kegiatan promosi suatu perusahaan menggunakan acuan/bauran promosi. Menurut Lupiyoadi (2013:178) unsur dari bauran promosi diantaranya periklanan (advertising), penjualan perseorangan (personal selling), promosi penjualan (sales promotion), hubungan masyarakat (public relation), informasi dari mulut ke mulut (word of mouth) dan pemasaran langsung (direct marketing). Hal ini sesuai dengan strategi promosi yang dilakukan oleh PT Nuansa Wisata Prima Nusantara Tour \& Travel Jember dalam mempromosikan produk jasanya, yaitu pengiklanan (advertising) dengan melalui media cetak dan media elektronik seperti surat kabar, brosur, kartu nama, televisi dan Radio.

PT Nuansa Wisata Prima Nusantara Tour \& Travel Jember juga melakukan promosinya melalui penjualan perseorangan (Personal selling), yaitu dengan memberikan surat penawaran kepada calon peserta tour. Personal selling Pemasaran Langsung (Direct Marketing) juga termasuk promosi yang digunakan oleh perusahaan tersebut. Direct Marketing merupakan komunikasi secara langsung yang digunakan dari mail telepon fax, email atau internet untuk mendapatkan tanggapan langsung dari konsumen secara jelas. Promosi 
pemasaran langsung ini dilakukan PT Nuansa Wisata Prima Nusantara Tour \& Travel Jember melalui media sosial

Strategi orang/SDM adalah orang-orang yang terlibat langsung dalam menjalankan segala aktifitas perusahaan, dan merupakan factor yang memegang peran penting bagi semua organisasi. Untuk mencapai kualitas sumber daya manusia yang terbaik, PT Nuansa Wisata Prima Nusantara Tour \& Travel Jember memberikan pelatihan pada karyawan serta mengadakan evaluasi kinerja pada karyawan. Pelatihan dan evaluasi karyawan ini dilakukan mengingat bahwa unsur orang/SDM bukan hanya memegang peranan penting dalam melakukan hubungan kontak langsung dengan konsumen sehingga berkaitan erat dengan pemasaran internal perusahaan itu sendiri. Hal ini sesuai dengan pendapat Lupiyoadi (2013:98) mengungkapkan bahwa pentingnya SDM dalam pemasaran jasa berkaitan erat dengan pemasaran internal (internal marketing) yang merupakan interaksi atau hubungan antara setiap karyawan dan departemen dalam suatu perusahaan. Tujuan dari adanya hubungan tersebut adalah untuk mendorong kinerja SDM dalam memberikan kepuasan kepada konsumen.

Penampilan fisik suatu perusahaan sangat berpengaruh sekali terhadap konsumen untuk membeli atau menggunakan produk jasa yang ditawarkan. Lovelock (dalam Alma \& Hurriyati, 2008:166-167) mengemukakan bahwa perusahaan melalui tenaga pemasarnya menggunakan tiga cara dalam mengelola bukti fisik yang strategis, yaitu (a) An Attention-Creating Medium; perusahaan jasa melakukan differensiasi dengan pesaing dan membuat sarana fisik semenarik mungkin untuk menjaring pelanggan dari target pasar. (b) As a MessageCreating Medium; menggunakan simbol atau isyarat untuk mengkomunikasikan secara insentif kepada audiens mengenai kekhususan kualitas dari produk jasa. (c) An Effect-Creating Medium; baju seragam yang berwarna, bercorak, suara dan desain untuk menciptakan sesuatu yang lain dari produk jasa yang ditawarkan. Hal ini sesuai dan telah dilakukan PT Nuansa Wisata Prima Nusantara Tour \& Travel Jember dimana perusahaan jasa tersebut melakukan pengadaan Cafetaria yang sangat cocok untuk proses transaksi. Adanya cafetaria tersebut sebagai upaya perusahaan untuk melakukan differensiasi dengan pesaing dan membuat sarana fisik yang menarik untuk menjaring pelanggan dari target pasar. Berdasarkan An Effect-Creating Medium dalam menciptakan sesuatu yang lain dari produk jasa yang ditawarkan PT Nuansa Wisata Prima Nusantara Tour \& Travel Jember mengadakan seragam (uniform) yang berwarna dan bernuansa sama. Selain sebagai identitas perusahaan dan untuk menciptakan sesuatu yang lain dari produk jasa yang ditarwarkan.

Karakteristik jasa yang tidak dapat disimpan merupakan suatu hal yang membedakan bauran pemasaran barang dan jasa, karena dalam bauran pemasaran jasa membutuhkan proses. Alma \& Hurriyati (2008:167) menjelaskan bahwa proses dalam jasa merupakan faktor utama dalam bauran pemasaran jasa seperti pelanggan jasa akan sering merasakan sistem penyerahan jasa sebagai bagian dari jasa itu sendiri. Selain itu keputusan dalam manajemen operasi adalah sangat penting untuk suksesnya pemasaran jasa. Hal ini berarti beberapa perusahaan tertentu harus memiliki cara tersendiri dalam melayani konsumennya. Begitu juga PT. Nuansa Wisata Prima Nusantara Tour \& Travel Jember memiliki cara unik dan khusus dalam memuaskan konsumennya. Cara tersebut diantaranya memberikan doorprize dan dokumentasi perjalanan wisata kepada para peserta tour. Selama berwisata PT. Nuansa Wisata Prima Nusantara Tour \& Travel Jember juga menjamin adanya asuransi, karena memastikan konsumen selamat hingga akhir acara, dan asuransi dapat diklaim apabila terjadi kecelakaan atau memenuhi syarat diajukan klaim tersebut.

\section{PENUTUP}

Berdasarkan hasil penelitian, maka dapat diambil kesimpulan bahwa PT. Nuansa Wisata Prima Nusantara Tour \& Travel Jember merupakan salah satu perusahaan yang bergerak dalam industri pariwisata khususnya dalam bidang biro perjalanan yang terdapat di kota Jember. Dalam menjalankah usaha jasanya PT. Nuansa Wisata Prima Nusantara Tour \& Travel Jember menerapkan strategi pemasaran yang mengacu pada strategi bauran pemasaran atau biasa disebut marketing mix diantaranya produk (product), harga (price), tempat (place), promosi (promotion), orang/SDM (people), bukti fisik (physical evidence) dan proses (process). Unsurunsur bauran pemasaran tersebut dijadikan sebagai perangkat/alat oleh PT. Nuansa Wisata Prima Nusantara Tour \& Travel Jember untuk mrncapai tujuan pemasarannya dalam pasar sasaran.

\section{DAFTAR PUSTAKA}

Alma, B. dan R. Hurriyati. 2008. Manajemen Corporate \& Strategi Pemasaran Jasa Pendidikan. Bandung: Alfabeta.

Alma, B. 2014. Manajemen Pemasaran Dan Pemasaran Jasa. Bandung: Alfabeta. 
DOI: 10.19184/jpe.v13i1.10422

Kotler, P. 2000. Manajemen Pemasaran, jilid 2. Terjemahan, Jakarta: Prenhallindo.

Lupiyoadi, R. 2013. Manajemen Pemasaran Jasa. Edisi 3. Jakarta: Selemba Empat.

Tjiptono, F. 2002. Strategi Pemasaran. Yogyakarta: CV. Andi Offset.

Tjiptono, F., G. Chandra. dan D. Adriana. 2008. Pemasaran Strategik, Edisi Pertama, Cetakan Pertama. Yogyakarta: CV. Andi Offset.

Universitas Jember. 2016. Pedoman Penulisan Karya Ilmiah. Jember: Badan Penerbit Universitas Jember.

Yoeti, O. A. 2006. Tour and Travel Manajemen. Jakarta: PT. Prandya Paramita. 